\title{
Discharge, Nitrate Load, and Residence Time of Ground Water in the Chesapeake Bay Watershed
}

\author{
by Scott W. Phillips, Michael J. Focazio, and L. Joseph Bachman
}

\section{Summary of Major Findings}

- Ground water contributes more than half (54 percent) of the total annual flow of streams in the Chesapeake Bay watershed.

- The ground-water nitrate load contributes about half (48 percent) of the total annual nitrogen load of streams entering the Bay.

- The apparent ages (residence times) of water collected from springs range from modern (0-4 years) to more than 50 years, with 75 percent of the ages less than 10 years.

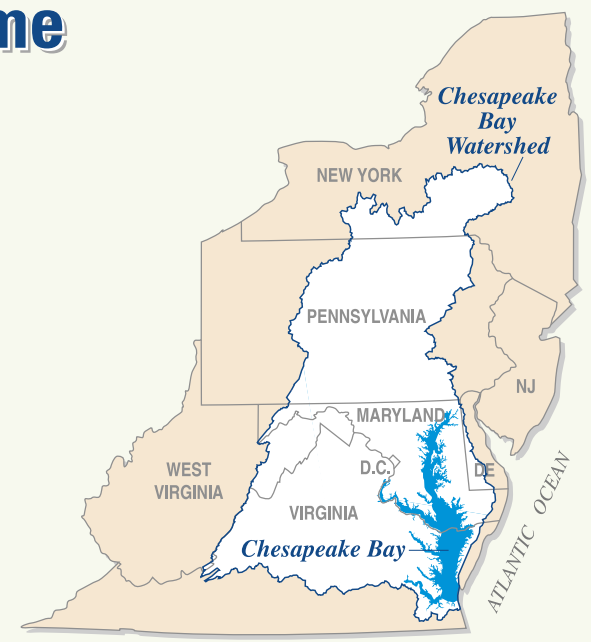

Figure 1. Chesapeake Bay watershed and surrounding area.

- The discharge, nitrate load, and residence time of ground water vary in the watershed due to differences in combinations of rock type and physiographic province (known as hydrogeomorphic regions), and land use.

- Quantifying the discharge, nitrate load, and residence time of ground water in the Chesapeake Bay watershed assists in developing an understanding of the movement of nutrients from their sources to streams, and in determining the "lag time" between the implementation of management actions and distinguishable improvement in surfacewater quality.

\section{Role of ground $w$ ater in the Chesapeake Bay watershed}

Ground-water discharge to

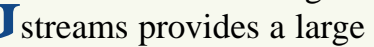
amount of flow that eventually enters the Chesapeake Bay. Thus, quantifying the discharge, nitrate load, and residence time of ground water in the Chesapeake Bay watershed (fig. 1) assists in developing an understanding of the movement of nutrients from their sources to streams. Some of the nutrients that are applied to the land surface, especially nitrogen, infiltrate into the underlying ground-water system. The nitrate is transported through shallow aquifers and discharges to springs and streams, thereby increasing the nitrate load to streams. If nitrate is assumed to move with the ground water, the residence time of water, which is the average time required for ground water to flow from areas of recharge to areas of discharge, can be used to estimate the rates of chemical transport. The residence time also provides an estimate of the "lag time" between implementation of management actions to reduce nutrient loads and a distinguishable improvement in surface-water quality.

This fact sheet presents an overview of discharge, nitrate load, and residence times of ground water in the Chesapeake Bay watershed based on the findings of two recent U.S. Geological Survey (USGS) reports: Bachman and others, 1998, and Focazio and others, 1998. The technical findings are part of the USGS Place-Based Studies Program (formerly known as the Ecosystem Program), which is studying the response of the Bay ecosystem to changes in nutrient inputs and natural conditions. The findings are being used by the Chesapeake Bay Program (CBP) to better understand the sources and delivery of nutrients, and the management actions to reduce nutrient loads to rivers and streams that drain into the Chesapeake Bay. Nutrients are of special concern because they contribute to eutrophication and low levels of dissolved oxygen in the Bay.

\section{Discharge of ground water to streams entering the Chesapeake Bay}

Ground water enters the

Chesapeake Bay in two ways: as base flow to streams and rivers that drain to the Bay, or as discharge from shallow aquifers directly to the Bay and its tidal tributaries. USGS technical efforts have focused on ground water that discharges to streams and rivers because it is considered to be the largest source of ground water and associated nitrate load to the Bay. Streamwater consists of direct runoff or overland flow, soil water, and ground water (fig. 2). Direct runoff is rain or snowmelt that flows directly over the land surface to streams. Soil water may mix with infiltrating precipitation and discharge to streams during and after storms. Ground-water discharge, or base flow, enters the streams from the saturated zone of an aquifer. Streamflow data collected at 276 sites in the Chesapeake Bay watershed (fig. 3) were analyzed using hydrograph-separa- 


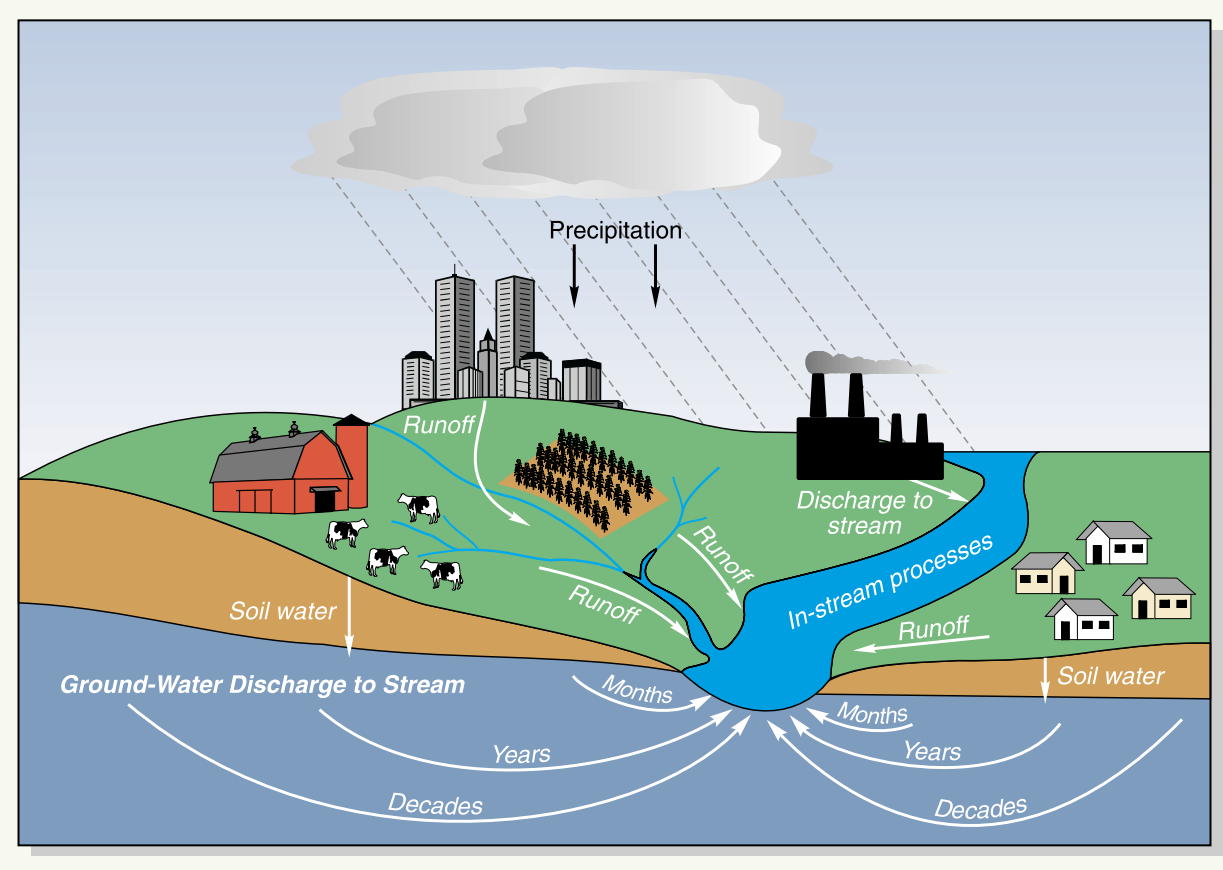

Figure 2. Nutrient movement in the ground-water-flow system.

tion techniques (Sloto and Crouse, 1996) to estimate the amount of total streamflow that is contributed by ground water. All sites had at least 4 years of streamflow data with some sites having more than 25 years of data. Groundwater contributions to total streamflow at these sites ranged from 16 to 92 percent, with a median value of 54 percent. This means that in an average year, of the 50 billion gallons of streamflow that enter the Bay each day, nearly 27 billion gallons are from ground water.

The underlying rock type and physiographic province influence the range of ground-water discharge values. These characteristics were used to divide the Chesapeake Bay watershed into eleven "hydrogeomorphic regions" or HGMRs, which are shown in figure 3. The characteristics of the rock type in each HGMR provide a surrogate for permeability and mineral composition of aquifers. The four major rock types used in the classification are unconsolidated, crystalline, carbonate, and siliciclastic. The HGMR physiographic province represents slope and relief characteristics, and thus hydrologic gradients. The six major physiographic provinces in the study area are the Coastal Plain, Piedmont, Mesozoic Lowland, Blue Ridge, Valley and Ridge, and Appalachian Plateau.

The contribution of ground-water discharge to total streamflow was highest in the Valley and Ridge Carbonate HGMR, followed by regions of unconsolidated sediments (Coastal Plain HGMRs) and crystalline bedrock (Piedmont and Blue Ridge HGMRs) (fig. 4). The lowest amounts of groundwater discharge were in the Mesozoic Lowland Siliciclastic HGMR. High amounts of ground-water discharge to streams in the Coastal Plain HGMRs are a consequence of well-drained soils and flat topography, which favor infiltration of precipitation into shallow aquifers. The underlying unconsolidated sediments, which are a combination of sands, silts, and clays, are relatively permeable and therefore capable of yielding large quantities of water. In contrast, ground water west of the Fall Line (the zone between unconsolidated sediments and bedrock, shown in figure 3 ) flows through fractures in consolidated and weathered bedrock. The conceptual ground-water-flow diagram shown in figure 5 helps to illustrate that the amount of ground water in shallow bedrock aquifers is influenced by the topographic relief, soil thickness and permeability, thickness of the overlying regolith (weathered bedrock), and the amount and interconnectiveness of fractures or solution cavities. The high amounts of ground-water discharge to streams in carbonate rocks of the Valley and Ridge HGMR are caused by permeable soils and generally low relief that promotes infiltration, and a high degree of fracturing and solution-enlarged fractures that transmit large quantities of water. Areas underlain by crystalline rocks (Piedmont Crystalline and Blue Ridge Crystalline HGMRs) have steeper topography and moderately drained soils so precipitation does not infiltrate as readily into the aquifers. A permeable mantle of colluvium and regolith generally covers the slopes of hills, however, and acts as a reservoir for ground water. Areas underlain by siliciclastic rocks (Appalachian Plateau Siliciclastic and Mesozoic Lowland Siliciclastic HGMRs) have lesser amounts of ground-water discharge to streams because of poorly drained soils and/or steeper topography that promotes overland runoff over infiltration, and bedrock with low fracture connectivity.

The amount of ground water contributing to total streamflow also varies with the amount of annual precipitation. Dry years generally result in a higher contribution of ground water to total flow, whereas wet years generally result in a greater amount of direct runoff to total streamflow. Variations in annual precipitation cause a fluctuation of 10 to 20 percent in ground-water contributions to total streamflow.

\section{Ground-w ater nitrate loads deliv- ered to streams}

The amount of nitrate in ground water depends on a number of factors, including the land use, the amount of nitrogen applied to the land surface, and the presence of dissolved oxygen in the aquifer (Speiran and others, 1998). For example, inputs of nitrogen are generally higher in urban and agricultural areas than forested areas. Therefore, a higher potential exists for nitrogen to infiltrate into the underlying soil zone and aquifer. Nitrogen is present in several forms in ground water depending on the availability of dissolved oxygen, and the dissolved oxygen will be influenced by both the soil and aquifer composition. Organic material within soil or aquifer material reacts with dissolved oxygen, removing it from the water. Finegrained soils and aquifer materials commonly contain higher amounts of organ- 


\section{EXPLANATION}

(Stream discharge was measured at all stations shown.)

A Stations for which only stream discharge was measured

$\triangle$ Stations for which loads were computed for base-flow nitrate, total-flow nitrate, or total-flow total nitrogen

Stations for which loads were computed for base-flow nitrate and total-flow nitrate only

$\nabla$ Stations for which loads were computed for base-flow nitrate and total-flow nitrogen only

$\boldsymbol{\nabla}$ Stations for which loads were computed for base-flow nitrate, total-flow nitrate, and total-flow total nitrogen

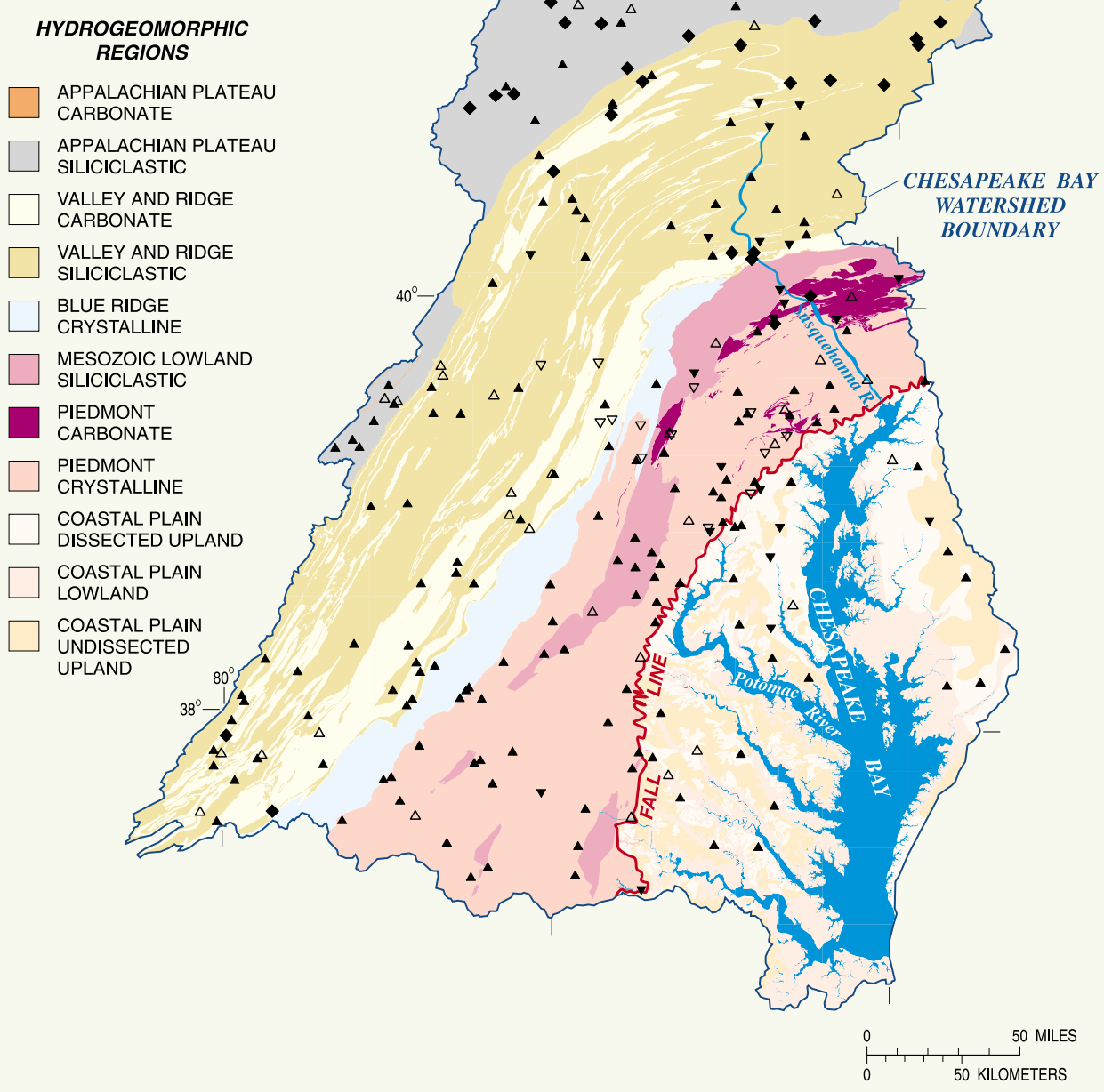

Figure 3. Location of stations with discharge measurements, stations with load estimates, hydrogeomorphic regions, and Fall Line.

ic materials than do coarser materials, and therefore less dissolved oxygen. Where dissolved oxygen is abundant, nitrate is the principal form of nitrogen in ground water because bacteria may chemically oxidize (nitrify) ammonia to nitrate. Nitrate is of concern because it dissolves in, and flows with, ground water. Where dissolved oxygen is limited, the concentrations of nitrate in ground water tend to be low because bacteria chemically reduce (denitrify) nitrate to nitrogen gas or to ammonia if sufficient organic material is present.

Results from a previous study of nutrient loads (Langland and others, 1995) were used to quantify groundwater nitrate loads contributing to the total nitrogen load in streams in the Chesapeake Bay watershed and their distribution in HGMRs. Ground-water nitrate loads were determined by use of ground-water discharge information and associated water-quality data to estimate the concentration of nitrate in streamflow during ground-water discharge (base-flow) conditions.

Ground-water nitrate loads contributed nearly half (48 percent) of the total nitrogen load to streams in the
Chesapeake Bay watershed, with a range at individual sites of 17 to 80 percent. The ground-water nitrate loads were converted to yields (load divided by drainage area) to allow comparisons between different HGMRs and their respective land use. Unfortunately, ground-water nitrate load and total nitrogen load data were available for far fewer stations (48) than those used to compute ground-water discharge, and therefore the data set could not be used to conduct statistical tests between ground-water nitrate yields and all of the HGMRs. In four HGMRs where statistical tests could be conducted, however, higher ground-water nitrate yields were detected in the Valley and Ridge Carbonate and Siliciclastic HGMRs, and the Piedmont Crystalline HGMR. The lowest ground-water nitrate yield was in the Appalachian Plateau Siliciclastic HGMR. In general, the highest ground-water nitrate yields are in HGMRs with higher amounts of agricultural land use, while the lowest ground-water nitrate yield corresponds to higher amounts of forested land use (fig. 6).

\section{Preliminary estimates of resi- dence times and apparent ages of ground w ater}

Estimation of ground-water residence time is very complex, especially in the varied geologic settings in the Chesapeake Bay watershed. Groundwater residence times were estimated using several approaches. Chemical isotopic tracers provide the most direct approach for estimating the age of ground water and associated residence time. Chlorofluorocarbons (CFCs) were the primary tracers used in this study to date the ground water discharging at springs and in many of the monitoring wells sampled in previous studies. The CFC dating techniques are described in Busenberg and Plummer (1992). CFCs have entered the atmosphere since the 1940's, and are transported to ground water as precipitation infiltrates to the water table. The CFC concentrations are used to estimate an "apparent" age of ground water, which is the time that has elapsed since precipitation entered the ground-water-flow system and has been isolated from the atmosphere. The 


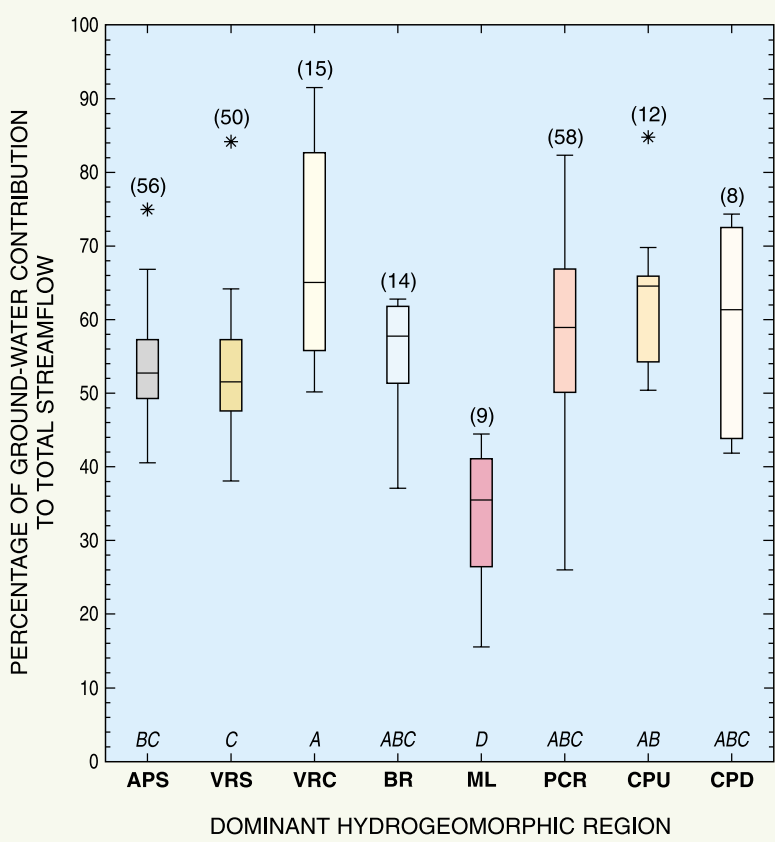

Figure 4. Distribution of ground-water contributions to streamflow.

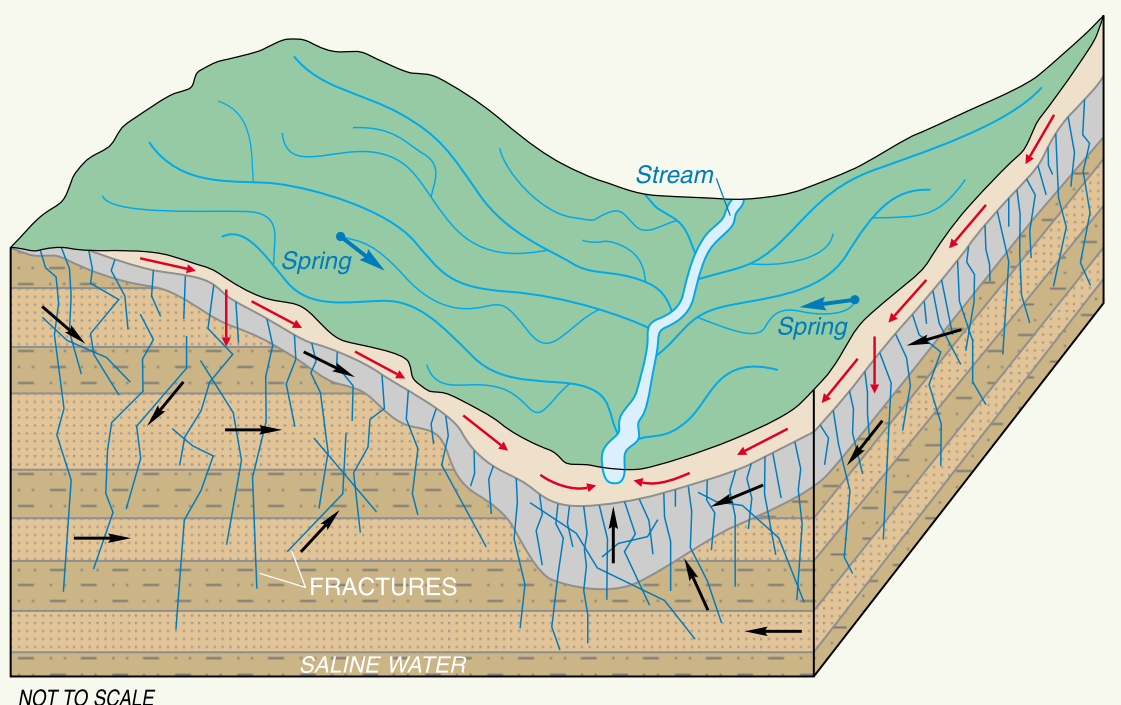

EXPLANATION

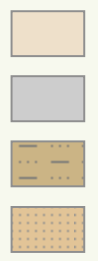

COLLUVIUM SOIL

WEATHERED BEDROCK (REGOLITH)

SILTSTONE

SANDSTONE OR SHALE

\section{EXPLANATION}

(12) Number of observations

* Outlier data value less than or equal to 3 times and greater than 1.5 times the

T Data value less than or equal to 1.5 times the interquartile range outside the quartile

75th percentile

Median

25th percentile

ABC Non-parametric Tukey Test (Medians with the same letter are not significantly different.)

\section{SELECTED}

HYDROGEOMORPHIC REGIONS

APS APPALACHIAN PLATEAU SILICICLASTIC VRS VALLEY AND RIDGE SILICICLASTIC

VRC VALLEY AND RIDGE CARBONATE

BR BLUE RIDGE CRYSTALLINE

ML MESOZOIC LOWLAND SILICICLASTIC

PCR PIEDMONT CRYSTALLINE

CPU COASTAL PLAIN UNDISSECTED UPLAND CPD COASTAL PLAIN DISSECTED UPLAND interquartile range outside the quartile

dating method is based on the assumption that gas loss, degradation, diffusion, or dispersion do not alter the concentrations of CFCs in ground water.

As part of this study, 60 water samples were collected from 48 springs in the Chesapeake Bay watershed for analysis of CFC concentrations to estimate an apparent age of ground water. Because a spring is a discharge point for a number of converging ground-water flow paths of different ages in an aquifer, the apparent age of a single sample collected from a spring may be considered a representative, or average, residence time for water in an aquifer. The apparent ages of water collected from springs sampled ranged from "modern" (0-4 years) to more than 50 years (fig. 7). The apparent age of water from 75 percent of the springs was less than 10 years, with another 10 percent between 10 and 20 years. The remaining ages were greater than 20 years, and included samples from two geothermal springs, which would indicate the presence of water from deeper ground-water-flow systems. About 20 percent of the samples were contaminated by local sources of CFCs and could not be dated. The ground-water samples were collected from the springs during an unusually high flow period and thus apparent ages may be younger that those under normal flow conditions.

The apparent age of the samples from the springs varied within each HGMR as much as between the HGMRs (table 1), but not enough data were collected to permit statistical tests of variance of apparent ages between the HGMRs. The apparent ages of the springs had the largest range in the Valley and Ridge HGMRs (modern to 33 years) and the Piedmont Crystalline HGMR (modern to 34 years). A smaller range of ages (modern to about 10 years) was seen in the remaining HGMRs that were sampled: the Coastal Plain, Piedmont Carbonate, Mesozoic Lowland Siliciclastic, and Blue Ridge Crystalline. Units in the Appalachian Plateau were not sampled. Where existing apparent age data from wells were available in a local study area, the ages of water in those wells were fairly consistent with the ranges of ages from the springs in the associated HGMR.

Focazio and others (1998) also examined data for tritium (which is 


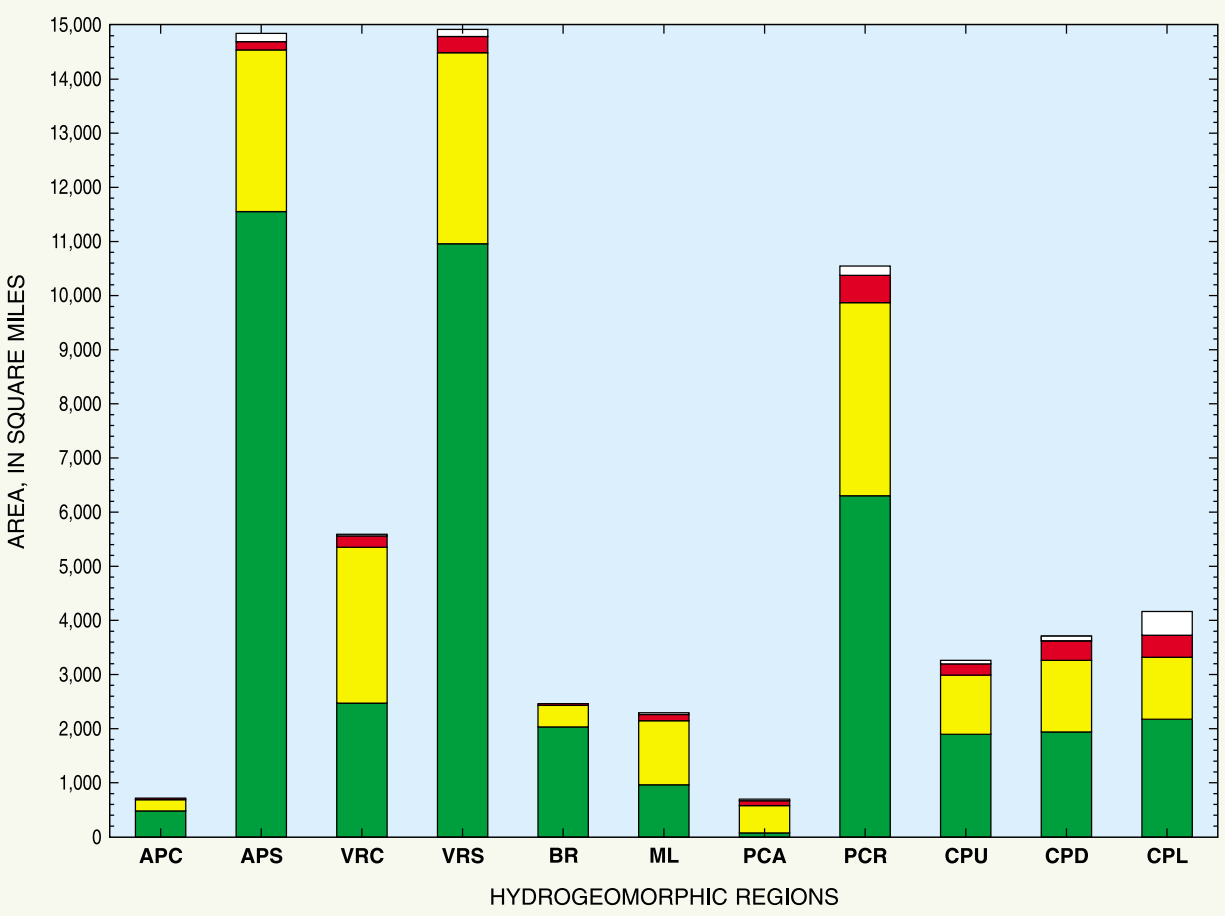

EXPLANATION

\begin{tabular}{|l} 
LAND USE \\
$\square$ OTHER \\
$\square$ URBAN \\
$\square$ AGRICULTURE \\
$\square$ FOREST
\end{tabular}

HYDROGEOMORPHIC REGIONS

\begin{abstract}
APC APPALACHIAN PLATEAU CARBONATE APS APPALACHIAN PLATEAU SILICICLASTIC VRC VALLEY AND RIDGE CARBONATE VRS VALLEY AND RIDGE SILICICLASTIC BR BLUE RIDGE CRYSTALLINE ML MESOZOIC LOWLAND SILICICLASTIC
\end{abstract}

Figure 6. Distribution of land uses within the Chesapeake Bay watershed and within each hydrogeomorphic region (HGMR).

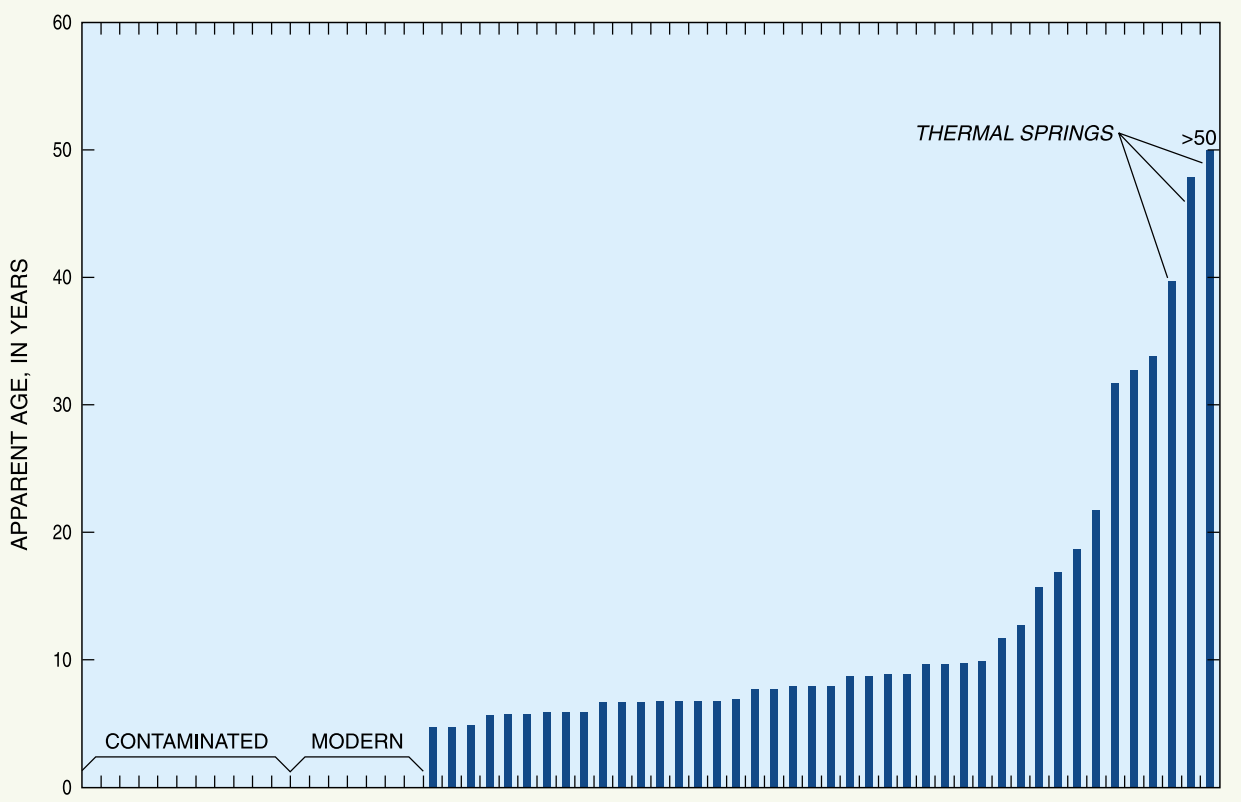

SPRING-WATER SAMPLE

Figure 7. Apparent ages (residence times) of water collected from springs in the Chesapeake Bay watershed in September and November 1996. another tracer that can be used to estimate ground-water residence times) collected in a previous study in the Potomac and Susquehanna River Basins (Michel, 1992). Long-term tritium records were used to calculate residence times for water in seven river basins in the United States and to determine the percentage of annual runoff attributed to "within-year runoff" and the percentage from "long-term reservoirs" (older ground water). This approach is similar to the hydrograph-separation techniques used to estimate the amount of ground water contributed to a stream. The Potomac River at Point of Rocks, Md., had the longest residence time (20 years) of all seven basins. The Potomac has a low percentage of within-year runoff (46 percent) and a correspondingly high percentage of long-term reservoirs (54 percent). For the other site in the Chesapeake Bay watershed, the Susquehanna River at Harrisburg, Pa., Michel (1992) calculated a residence time of 10 years, with 20 percent of the water in the long-term reservoir and 80 percent as within-year runoff. Focazio and others (1998) applied a similar approach to the Susquehanna River and estimated a residence time of 10-20 years, and about even percentages between the "within-year" and "longterm" reservoirs. Tritium data for rivers are very limited from the 1960's and 1970's, and concentrations have been too low in recent rainfall for the technique to be applied to more rivers in the Chesapeake Bay watershed.

\section{Implications for Chesapeake Bay restoration and future information needs}

Understanding the discharge, nitrate load, and residence time of ground water in the Chesapeake Bay watershed will help resource managers develop actions to reduce nutrient loads entering the Bay. The CBP is working to reduce nutrient loads to the Bay by developing tributary strategies and using a watershed model to predict the effectiveness of the strategies. Current versions of the watershed model do not address all aspects of ground water however, and do not account for groundwater residence times in particular. The $\mathrm{CBP}$ can also use ground-water infor- 
Table 1. Distribution of apparent ages (residence times) of water from springs in different hydrogeomorphic regions in the Chesapeake Bay watershed

\begin{tabular}{ll|}
\multicolumn{1}{c}{ HYDROGEOMORPHIC REGION } & APPARENT AGE OF WATER (years) \\
\hline COASTAL PLAIN & 6 to 12 \\
\hline PIEDMONT CRYSTALLINE & modern $(0-4$ years $)$ to 34 \\
PIEDMONT CARBONATE & modern to 7 \\
MESOZOIC LOWLAND SILICICLASTIC & modern to 9 \\
BLUE RIDGE CRYSTALLINE & modern to 8 \\
VALLEY AND RIDGE SILICICLASTIC & modern to 33 \\
VALLEY AND RIDGE CARBONATE & modern to 32 \\
\hline
\end{tabular}

mation in the revision of nutrient-reduction strategies for the Bay tributaries and the watershed model to understand the "lag time" between implementation of management actions and the reduction of nutrient concentrations in rivers draining to the Bay.

The CBP may consider management actions that promote infiltration of nitrogen into the subsurface where conditions for the potential of denitrification exist. An understanding of groundwater discharge, nitrate load, and subsurface characteristics near streams can also be used to guide placement of forest buffers in riparian areas to provide maximum benefit for nutrient reductions. Some nutrient-management actions may affect the quality of ground water that is used for public supply.

Resource managers need to consider situations where management actions may promote the migration of nitrogen and other chemicals into shallow aquifers where ground water is used as a drinking-water resource.

The ecological health of any stream in the watershed is affected by ground-water discharge. Ground water supplies from 16 to 92 percent of the flow to streams and a greater percentage during summer months, which is a critical time for biological communities. Land-use changes that affect the amount and quality of ground water discharging to streams must be considered to ensure healthy stream ecology and habitat.

Although the USGS has provided preliminary information to address these issues, additional information is needed to further document the distribution of ground-water nitrate loads and residence times in different HGMRs.
Additionally, information is needed to document changes in residence times and nitrate loads as hydrologic conditions and sources change, to map the subsurface characteristics that will promote denitrification, and to relate ground water to stream ecology.

This overview was developed from information in two USGS reports:

Ground-Water Discharge and BaseFlow Nitrate Loads of Nontidal Streams, and Their Relation to a Hydrogeomorphic Classification of the Chesapeake Bay Watershed, Middle Atlantic Coast,

U.S. Geological Survey

Water-Resources Investigations Report 98-4059

by Bachman, L.J., Lindsey, B.D., Brakebill, J.W., and Powars, D.S., 1998,

\section{and}

Preliminary Estimates of Residence Times and Apparent Ages of Ground Water in the Chesapeake Bay Watershed, and Water-Quality Data From a Survey of Springs, U.S. Geological Survey Water-Resources Investigations Report 97-4225

by Focazio, M.J., Plummer, L.N., Böhlke, J.K., Busenberg, E., Bachman, L.J., and Powars, D.S., 1998.

\section{Additional References Cited}

Busenberg, E. and Plummer, L.N., 1992, Use of chlorofluorocarbons as hydrologic tracers and age-dating tools: Water Resources Research, v. 28, p. 2275-2283.

Harlow, G.E., Jr., and LeCain, G.D., 1991, Hydraulic characteristics of, and ground-water flow in, coal-bearing rocks of southwestern Virginia: U.S. Geological Survey Water-Supply Paper 2388, 36 p.

Langland, M.J., Lietman, P.L., and Hoffman, S., 1995, Synthesis of nutrient and sediment data for watersheds within the Chesapeake Bay drainage basin: U.S. Geological Survey Water-

Resources Investigations Report 954233, $121 \mathrm{p}$.

Michel, R.L., 1992, Residence times in river basins as determined by analysis of long-term tritium records: Journal of Hydrology, v. 130, p. 367378.

Sloto, R.A., and Crouse, M.Y., 1996, HYSEP — a computer program for streamflow hydrograph separation and analysis: U.S. Geological Survey WaterResources Investigations Report 964040, 46 p.

Speiran, G.K., Hamilton, P.A., and Woodside, M.D., 1998, Natural processes for managing nitrate in ground water discharged to Chesapeake Bay and other surface waters - more than forest buffers: U.S. Geological Survey Fact Sheet 178-97, 6 p.

\section{For further information contact:}

Chesapeake Bay Programs Coordinator U.S. Geological Survey 8987 Yellow Brick Road Baltimore, M aryland 21237

or visit the USGS Chesapeake Bay Homepage: http://chesapeake.usgs.gov/chesbay

For more information on the Chesapeake Bay Program: http://w w w ,chesapeakebay.net

FS-150-99 